\title{
The Effect of Consumer Behavior on Consumer's Interest to Buy Products Mr. Beta Pomade in UMKM in South Oesapa Village
}

\author{
Muhammad Nur Uran ${ }^{1, *}$ Ronald P.C. Fanggidae ${ }^{1}$ Antonio E.L. Nyoko ${ }^{1}$ \\ ${ }^{I}$ Department of Management, Nusa Cendana University, Kupang, Indonesia \\ *Corresponding author. Email: adeuran88548@gmail.com
}

\begin{abstract}
Pomade has evolved into a way of life for certain men because it is a cosmetic product that is used to enhance the appearance of males. In Kupang City, there have been numerous micro, small, and medium-sized enterprises (MSMEs) and Pomade supply stores, one of which is the MSMEs Mr. BETA Pomade in South Oesapa Village, another of which is the MSMEs Mr. BETA Pomade in South Oesapa Village. The subject of this study is Mr. BETA Pomade, a micro, small, and medium-sized firm in Oesapa Selatan Village, Kupang City, which is the subject of this study. Mr. BETA Pomade products in South Oesapa Village were investigated for the objective of determining the impact of customer behavior on consumer interest in Mr. BETA Pomade products. The quantitative research methods that were employed in this study are described below. UMKM South Oesapa Village is the target audience for this study, which includes Mr. BETA Pomade customers. The number of participants in this study totaled 100 individuals. The assumption test, multiple regression test, the $t$ test, the $\mathrm{f}$ test, and the coefficient of determination test were all employed in the data analysis. After analyzing the collected research data, the partial test results reveal that the Consumer Behavior variable, which is represented by Cultural factors, Social factors, and Personal factors, has no significant impact on consumers' purchasing interest in Mr. BETA Pomade products in UMKM in South Oesapa Village, whereas psychological factors have a significant impact on consumers' purchasing interest in micro, small, and medium-sized enterprises in South Oesapa Village. The results of a simultaneous test show that consumer behavior variables in the form of cultural factors, social factors, individual characteristics (such as gender and age), as well as psychological characteristics, have a statistically significant impact on consumer interest in Mr. BETA Pomade in UMKM South Oesapa Village.
\end{abstract}

Keywords: Buying interest, Consumer behavior, Micro, small and medium enterprises.

\section{INTRODUCTION}

The government places a high priority on the growth of Micro, Small, and Medium Enterprises (Usaha Mikro Kecil dan Menengah-UMKM). Not only does Indonesia have the most UMKM, but UMKM can also survive the global crisis. Based on the Law of the Republic of Indonesia No. 20 of 2008 on Micro, Small, and Medium Enterprises, the government is constantly attempting various initiatives through the State Ministry of Cooperatives and Small and Medium Enterprises so that more and more individuals are willing to pursue the world of entrepreneurship in the form of establishing UMKM.
Over time, many people have started to run UMKM, starting from UMKM in culinary, cosmetic and fashion, souvenirs, technology and many others. One of them is UMKM Mr. BETA POMADE which is located in South Oesapa Village. Mr. BETA POMADE is an UMKM in the cosmetic sector that sells hair oil specifically for men. Mr. BETA POMADE provides a variety of scents, packaging sizes, and different levels to support the appearance of consumers. The following table (Table 1) is the sales data for each year of Mr. BETA POMADE in UMKM, South Oesapa Village.

From the Table 1, it refers to the increase in sales every year in the last 3 years, and the bubble gum aroma has become the most sold compared to other scents in the last 3 years. Consumer behavior is an important 
Table 1. Pomade's sales data

\begin{tabular}{|c|l|c|}
\hline Year & Scent & Amount (years) \\
\hline 2018 & Vanila & 420 pcs \\
\hline 2018 & Bubblegum & 480 pcs \\
\hline 2018 & Cola & 360 pcs \\
\hline 2019 & Vanila & 540 pcs \\
\hline 2019 & Bubblegum & 600 pcs \\
\hline 2019 & Cola & 420 pcs \\
\hline 2020 & Vanila & 660 pcs \\
\hline 2020 & Bubblegum & 780 pcs \\
\hline 2020 & Cola & 420 pcs \\
\hline
\end{tabular}

Source: UMKM in South Oesapa Village (Processed, 2021)

element in buying interest in a product or service. according to Kotler \& Keller [1], consumer behavior is influenced by four factors, namely: cultural, social, personal and psychological. It is necessary to know the factors to influence consumer behavior in creating buying interest to Mr. BETA POMADE products, although there are many types of pomade in Kupang City.

The purpose of this study is to determine the influence of cultural factors, social factors, personal factors, and psychological factors on consumer purchasing interest in Mr. BETA Pomade in micro, small, and medium enterprises, South Oesapa Village.

\section{LITERATURE REVIEW \& HYPOTHESIS DEVELOPMENT}

\subsection{Consumer Behavior}

As defined by Kotler \& Keller [1] consumer behavior is the study of how people and groups make decisions about what they want and how they get it. Stimulus and response model is a starting point for understanding buyer behavior, which states that marketing stimuli, such as price, place, and promotion, and other environmental stimuli (economic, technological, political, and cultural), enter the buyer's consciousness and influence his or her decision-making process. Product choice, brand choice, dealer choice, purchase time, and the number of purchases are all affected by consumer characteristics and buyer decision processes, including problem recognition, information searching, evaluation, decisions, and post-purchase behavior. From the buyer behavior model above, Kotler $\&$ Armstrong [2], underlined the importance of studying how customers' traits influence their purchasing behavior and how cultural, social, personal, and psychological aspects impact consumer interest in a product or service.

\subsection{Buying Interest}

Selling interest, according to Kotler [3], can be defined as a consumer's reaction to seeing an object that indicates their want to purchase it. Consumers everywhere and at any time are confronted with the decision to buy something. According to Kotler [3] a person's preferred alternative will be reduced to a certain extent by the other's attitude and the consumer's motivation to comply with the other's wishes. It's up to the consumer to decide whether or not they are confident enough to purchase an item. There are three types of buying interest, according to Ferdinand [4], that is: transactional interest, which is a person's tendency to buy a product; referential stake, which is a person's tendency to recommend a product; and exploratory interest, which describes the behavior of someone who is always looking for information about the product he is interested in and looking for information to support the positive feelings he has about it.

The hypotheses of this study is stated as follows:

$\mathrm{H}_{1}$ : Cultural Factors In The Variable Of Consumer Behavior Affect The Variable Of Purchase Interest (Y) Of Mr. Beta Pomade Product

$\mathrm{H}_{2}$ : Social Factors In The Variable Consumer Behavior Affect The Variable Purchase Interest (Y) Of Mr. Beta Pomade Product

$\mathrm{H}_{3}$ : Personal Factors In The Variable Of Consumer Behavior Affect The Variable Of Purchase Interest (Y) Of Mr. Products. Beta Pomade Buying

$\mathrm{H}_{4}$ : Psychological Factors In The Consumer Behavior Variable Affect Theinterest Variable (Y) Of Mr. Beta Pomade Product

$\mathrm{H}_{5}$ : Consumer Behavior Variables Presented By Cultural Factors (X1), Social (X2), Personal (X3), Psychology (X4) Effect Together To Variable Interest Buy (Y)

\section{METHOD}

This research uses associative quantitative research. Quantitative approaches are used to analyze specific populations and samples, data gathering through research tools, and statistical data processing in order to evaluate prepared hypotheses. [5]. It was the goal of this study to examine the influence of cultural, social, personal, and psychological aspects on the purchasing interest of Mr. BETA Pomade at micro, small, and medium-sized businesses in South Oesapa Village. 


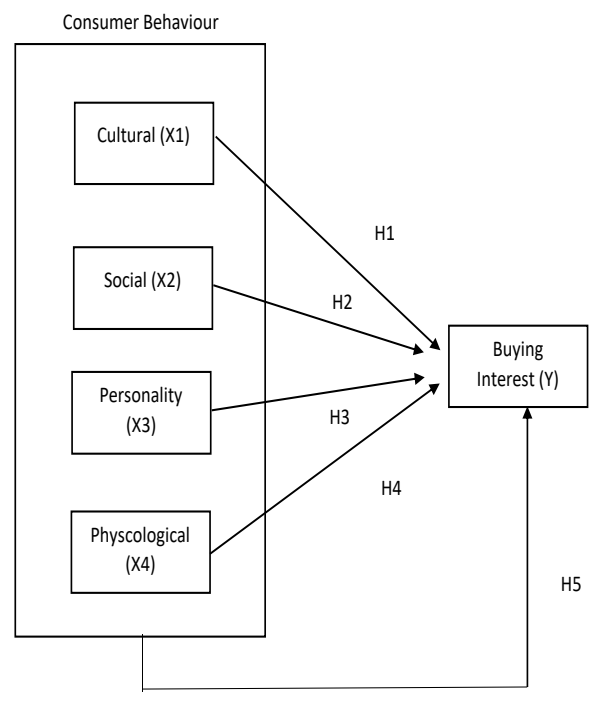

Figure 1 Thinking Framework

\section{RESULTS \& DISCUSSION}

This research uses the type of quantitative research. The population in this study were customers at UMKM Mr. BETA Pomade in South Oesapa Village. The sample of this study amounted to 100 people. Data processing and analysis was carried out using the SPSS program.

\subsection{The Influence of Cultural Factors on Buying Interest of UMKM Mr. BETA Pomade Consumer in South Oesapa Village}

Based on the results of the test (partial) shows that the cultural factors partially do not significantly influence the buying interest of UMKM Mr. BETA Pomade consumers which is indicated by the value of $\mathrm{t}$ count $(-0.141)<\mathrm{t}$ table $(1.985)$ and significance $(0.888)$ $>$ alpha (0.05) then $\mathrm{H} 0$ is accepted, means that cultural factors do not significantly influence the buying interest of UMKM Mr. BETA Pomade consumers in South Oesapa Village.

In the results of multiple linear regression test produces a negative value, means that cultural factors have an inverse effect on consumer buying interest. This means the more bigger the cultural factor in consumer behavior, the less interest in buying Mr. BETA Pomade Produts.

Cultural factors that are considered well by consumers are assessing Mr. BETA Pomade Products has good quality, but this has no significant effect on buying interest. This is not in accordance with the theory of Setiadi [6], says that the Cultural factor is the most important factor in decision-making behavior and buying behavior. This is because there also many similar products that has or better quality, and also not influenced by social groups or classes, so consumer buying interest is more influenced by other factors. In addition, based on the results of other studies, it can be said that within a period of 3 years it has not been considered as culture. This result is also different from the research of Laela [7], who states that consumer behavior is very influential on buying interest, which is shown between the two variables has a very high relationship. It means that the better consumer behavior, the consumer's buying interest will increase. Because, in this study, consumer behavior is very important before making a purchase.

\subsection{The Influence of Social Factors on Buying Interest of UMKM Mr. BETA Pomade Consumers in South Oesapa Village}

Based on the results of the t-test (partial) shows that social factors partially have no significant effect on buying interest of UMKM Mr. BETA Pomade consumer which is indicated by the value of tcount $(1.541)<$ ttable $(1.985)$ and significance $(0.127)>$ alpha (0.05) then $\mathrm{HO}$ is accepted, meaning that social factors do not significantly influence the buying interest of UMKM BETA Pomade consumers in South Oesapa Village.

The social factor that is considered well by consumers is the influence of friends, but this does not have a significant effect on buying interest. This is not in accordance with the theory of Anoraga [8], explains that in social factors, each role (Family, coworkers, role and social status and others) will affect a person's buying behavior. This is because not all consumers can be influenced or easily influenced by friends and coworkers, so consumer buying interest is more influenced by other factors. These results are also different from the results of the study of Laela [7], which states that consumer behavior is very influential on buying interest, which is shown between the two variables has a very high relationship. This means that the better consumer behavior, the consumer's buying interest will increase. This is because, in this study, consumer behavior is very important before making a purchase.

\subsection{The Influence of Personal Factors on Buying Interest of UMKM Mr. BETA Pomade Consumers in South Oesapa Village}

Based on the results of the t-test (partial) shows that the personal factor partially does not significantly influence buying interest UMKM Mr. BETA Pomade consumer which is indicated by the value of tcount $(1.960)<$ ttable $(1.985)$ and significance $(0.053)>$ alpha (0.05) then H0 is accepted, meaning that personal factors do not significantly influence the buying interest of UMKM Mr. BETA Pomade consumer in South Oesapa Village. 
Personal factors that are considered good by consumers are economic conditions or income, but this does not have a significant effect on buying interest. This is not in accordance with the theory of Kotler [3], which explains that personal characteristics (age and life cycle stage, occupation, economic circumstances, lifestyle, etc.) influence buying behavior. This is because economic factors / income, lifestyle, tastes or work do not affect consumer buying interest but are more influenced by other factors. These results are different too from the results of Laela's [7] study, states that consumer behavior is very influential on buying interest, which is shown between the two variables has a very high relationship. This means that the better consumer behavior, the consumer's buying interest will increase. This is because, in this study, consumer behavior is very important before making a purchase.

\subsection{The Influence of Psychological Factors on Buying Interest of UMKM Consumer for $\mathrm{Mr}$. BETA in South Oesapa Village}

Based on the results of the t test (partial) shows that psychological factors partially have a positive and significant influence on buying interest consumer product Mr. BETA Pomade which is indicated by the value of tcount (3.713) > ttable (1.985) and significance $(0.000)<$ alpha $(0.05)$ then $\mathrm{H} 0$ is rejected, meaning that psychological factors significantly influence the buying interest of UMKM Mr. BETA Pomade consumers in South Oesapa Village. This it can be interpreted that the higher the level of psychological factors will have an impact on increasing consumer interest in buying $\mathrm{Mr}$. BETA Pomade Produts in South Oesapa UMKM. Psychological factors have a significant effect because consumers prefer elements that exist in psychological factors, because of their motivation, perception, and knowledge about Mr. BETA Pomade Produts which makes many consumers choose psychological factors as the basis for their buying interest in Mr. BETA Pomade in UMKM, South Oesapa Village.

Psychological factors have a significant effect on buying interest because consumers feels they have to fulfill the need for the product. This is in accordance with the theory of Kotler [9], which says that the choice of goods purchased by a person is further influenced by psychological factors. so this is the factor that influences consumer behavior to decide to buy Mr. BETA Pomade Produts. This is in line with the research resultso of Laela [7], which states that consumer behavior is very influential on buying interest, which is shown between the two variables has a very high relationship. This means that the better consumer behavior, the consumer's buying interest will increase. This is because in this study, consumer behavior is very important before making a purchase.

\subsection{The Influence of Cultural Factors, Social Factors, Personal Factors and Psychological Factors on Consumer Purchase Interest of Mr. BETA Pomade Products at UMKM in South Oesapa Village}

Based on the results of the simultaneous test or $\mathrm{f}$ test, it can be concluded that the variables of Cultural factors, Social factors, Personal factors, and Psychological factors have a simultaneous effect on Buying Interest. Although there are 3 factors (Cultural factors, Social factors, and Personal factors) that do not have a significant effect and 1 significant factor, the psychological factor, it has a very dominant influence so that in general consumer behavior has a significant effect on consumer buying interest. Mr. BETA Pomade in UMKM, South Oesapa Village. This is due to cultural factors, social factors, personal factors, and psychological factors are the factors that are most often used by consumers as their consideration for buying products, this is corroborated by the opinion of Kotler \& Keller [10], consumer behavior is influenced by four factors, they are: cultural, social, personal and psychological.

Based on the analysis result of determination which shows that the percentage of the influence of the independent variable, etc consumer behavior (Cultural factors, Social factors, Personal factors, and Psychological factors) on the dependent variable (Buying interest) is $49.7 \%$ while the remaining $50.3 \%$ is influenced by other variables. which were not discussed in this study.

\section{CONCLUSION}

It can be concluded, based on the findings of the research conducted on UMKM Mr. BETA Pomade in South Oesapa Village regarding the influence of consumer behavior on consumer buying interest in $\mathrm{Mr}$. BETA Pomade in UMKM, South Oesapa Village that, based on the results of the partial test, the Consumer Behavior variable represented by Cultural factors, Social factors, and Personal factors does not significantly affect consumer buying interest in $\mathrm{Mr}$. BETA Pomade in UMKM, South Oesapa Village, The results of a simultaneous test show that the variables of consumer behavior such as cultural factors, social factors, individual characteristics and psychological characteristics have a significant impact on the purchasing interest of UMKM Mr. BETA Pomade consumers in the South Oesapa Village, as evidenced by the results of this study.

Mr. BETA Pomade in Oesapa Selatan Village comes highly recommended in this study for micro, small, and medium enterprises. SMEs should also pay attention to indicators directly related to psychological factors so that consumers can use these factors as a basis for 
purchasing Mr. BETA Pomade products. This is especially important because the psychological factor is the most significant and influential factor in the Consumer Behavior variable. Other aspects beyond cultural, societal, personal and psychological factors are needed for future research.

\section{REFERENCES}

[1] K. Kotler, P., \& Keller, Marketing Management. Jakarta: Erlangga, 2009.

[2] P. Kotler and G. Armstrong, Principles of Marketing (Edition 13). 2010.

[3] P. Kotler, "Manajemen Pemasaran edisi 13 jilid 1,” Erlangga. Jakarta, 2009.

[4] A. Ferdinand, "Metode penelitian manajemen," Semarang: Badan Penerbit Universitas Diponegoro, Semarang: Badan Penerbit Universitas Diponegoro, 2006.

[5] Sugiyono, Research Methodology, Quantitative Qualitative and $R \& B$. Bandung: Alfabeta, 2009.

[6] N. J. Setiadi, "Consumer Behavior: Concepts and implications for marketing strategy and research," Prenadamedia Media, Jakarta, 2003.

[7] T. Laela, "Pengaruh Perilaku Konsumen Dan Merek Produk Terhadap Minat Beli Produk Fashion Zoya,” J. Ekonologi Ilmu Manaj., vol. 2, no. 2, pp. 131-134, 2015.

[8] P. Anoraga, Business management. Jakarta: Rineka Cipta, 2000.

[9] P. Kotler, "Manajemen Pemasaran," Pemasaran, Manaj. Jilid, I II, 2005.

[10] P. Kotler and K. Keller, Marketing Management. Jakarta: Erlangga, 2011. 